Compiled in August, 1996

SUMMARY AND ABSTRACTS

Applied Research Units and Projects

1997 UCETF Program

ENERGY TASK FORCE

of the Urban Consortium

Prepared by 


\section{DISCLAIMER}

This report was prepared as an account of work sponsored by an agency of the United States Government. Neither the United States Government nor any agency thereof, nor any of their employees, make any warranty, express or implied, or assumes any legal liability or responsibility for the accuracy, completeness, or usefulness of any information, apparatus, product, or process disclosed, or represents that its use would not infringe privately owned rights. Reference herein to any specific commercial product, process, or service by trade name, trademark, manufacturer, or otherwise does not necessarily constitute or imply its endorsement, recommendation, or favoring by the United States Government or any agency thereof. The views and opinions of authors expressed herein do not necessarily state or reflect those of the United States Government or any agency thereof. 


\section{DISCLAIMER}

Portions of this document may be illegible in electronic image products. Images are produced from the best available original document. 


\section{CONTENTS}

\section{Overview}

Municipal Governments and Utility Policy Unit

Research Objectives

Projects and Lead Jurisdictions

Project Summaries, Participants and Partners

\section{Energy Usage and Supply Unit}

Research Objectives

Projects and Lead Jurisdictions

Project Summaries, Participants and Partners

Energy Efficiency for Local Needs and Economic Development Unit

Research Objectives

Projects and Lead Jurisdictions

Project Summaries, Participants and Partners

\section{Tèchnology Transfer Unit}

Research Objectives

Projects and Lead Jurisdictions

Project Summaries, Participants and Partners 


\section{OVERVIEW}

The Urban Consortium (UC), created by PTI, is a network of jurisdictions with populations of over 250,000. The UC provides a platform for research and enterprise through its Energy, Environment, Transportation, and Telecommunications and Information Task Forces. The UC provides a unique creative forum where elected and appointed officials and technical managers identify, test, and validate practical ways to improve the provision of public services and, where possible, generate new revenue opportunities.

Public Technology, Inc., the non-profit technology organization of the National League of Cities, the National Association of Counties, and the International City/County Management Association, creates and advances technology-based products, services, and enterprises in cities and counties nationwide.

Staffed by PTI, the UC addresses the critical needs of local governments through its Task Forces. The Urban Consortium Energy Task Force (UCETF) program has, since its inception, acted as a laboratory to develop, test solutions and share the resulting products or management approaches with the wider audience of local governments. It has addressed the overlap between energy and environment and economic development policy issues, and, is the nation's most extensive cooperative local government program to improve energy management and decision-making through applied research and technology cooperation.

Proposals to meet the specific objectives of the UCETF annual R\&D program are solicited from urban jurisdictions. Projects based on these proposals are then selected by the UCETF for direct conduct and management by staff of city and county governments. Projects selected for each year are organized in thematic units to assure effective management and ongoing peer-to-peer experience exchange, with results documented at the end of each program year.

\section{Specific R\&D Priorities}

Developed to meet both the defined needs of cities and counties as well as national priorities, major topics within the 1997 program are (1) Energy Usage and Supply; (2) Energy Efficiency for Local Needs and Economic Development; (3) Municipal Governments and Utility Policy; and (4) Technology Transfer.

\section{Partnership Development}

The UCETF has established partnerships with its city and county members, USDOE, energy utilities, and other organizations. Efforts have been placed on the expansion of these partnerships with the private industry, community organizations, state governments, national laboratories, and academia.

\section{Technology Transfer}

Successful projects are transferred to other cities and counties through specifically designed activities and reports, print and electronic media, videos, workshops and conferences. 
This summary contains short descriptions of the projects and participants in the 1997 UCETF program. For more information about this program and other UCETF projects, contact:

Judith Mondre, Chair

Philadelphia Energy Office

1401 JFK Boulevard, Suite 600

Philadelphia, PA 19102-1665

215/686-3904
Ama Frimpong

Public Technology, Inc.

1301 Pennsylvania Avenue, NW

Washington, DC 20004

202/626-2400 


\section{UCETF 1997 PROGRAM YEAR UNITS AND PROJECT DESCRIPTIONS}

\section{MUNICIPAL GOVERNMENTS AND UTILITY POLICY}

There is a lot of interest and need for information on the local impacts of the restructuring of the electricity industry. Local governments will be affected by the move toward greater competition in electricity in a number of ways. Competition offers the opportunity for cost savings through reduced energy bills for local governments, businesses and residents. Open access to transmission systems, and wholesale and retail wheeling will affect those local jurisdictions that currently offer exclusive utility franchises. Franchise fees, or other revenues received by local jurisdictions from utilities may be affected by changes in the industry. Opportunities for greater economic growth may be enhanced by lower electricity rates. But with lower rates come pressures on utilities to discontinue activities in a number of areas, including energy efficiency programs, low income efforts and research and development, that local governments have traditionally valued.

The UCETF 1997 program includes five projects examining various aspects of the utility restructuring issue.
San Jose, CA
Municipal Choices in a Restructured Utility
Marketplace
Chicago, $\mathrm{IL}$
Municipally Assisted Electric Competition for Industrial Parks
Columbus, $\mathrm{OH}$
Emerging Competition for Electricity: A Municipal Economic Development Opportunity
Portland, OR
Portland's GreenPower Partnership
Barnstable County, MA Competitive Franchise Conference and Workshop 
Municipal Choices in a Restructured Utility Marketplace

San Jose, CA

\begin{abstract}
Competition in the utility industry is becoming a reality. Solutions to this new reality will result from knowledge of changing conditions and the ability of local governments to influence rule making. Specific solutions will be needed to address the impacts of restructuring on municipal revenues, utility costs and energy management. This research will examine the impacts of utility restructuring on municipal revenues utility costs and energy management, and the emerging energy marketplace from perspective of local government operations. It will also document how to use the changes in utility industry practices to the net benefit of communities. The impacts on local governments from the coming transition to a more competitive electricity industry will also be examined.
\end{abstract}

\title{
Partners and Participants
}

A peer research relationship will be established between the City and other California cities through the Association of Bay Area Governments (ABAG) and the League of the California Cities (LCC).

Project Director: $\quad$ Rita Norton, Environmental Program Manager

Project Manager: Mary Tucker

Environmental Services Department

777 North First Street, Suite 450

San Jose, CA 95112

408/277-5533 Fax: 408/277-3608

Municipally Assisted Electric Competition for Industrial Parks

Chicago, IL

\begin{abstract}
The transition period of a more competitive electricity industry is coming slowly to Northern Illinois and is benefiting only a few customers. Because of this, the actual or potential role of the local government, who is a consumer, regulator, generator, and potentially aggregator/marketer of electricity, in defining the rules of competition and accelerating its introduction must be explored.
\end{abstract}

Chicago will investigate the potential role of the local government in bringing competitive electricity service to industrial sites. This project will consider the role of government as consumer, regulator, generator, and possibly aggregator/marketer of electricity. Options for creating competitive electricity supply options for industrial sites could include use of the local franchising authority, taking advantage of market developments, or promulgation of new rules and regulations. 
This project also has the potential to support local economic growth and job creation and retention. The underlying presumption of the proposed project is that alternative supply options would have to offer power at reduced costs compared to the regulated tariffs of the local power supplier. The availability of lower cost power would become a primary economic development incentive for companies that would be willing to locate or expand to Chicago but for the current and projected costs of electricity rates.

\title{
Participants and Partners
}

As part of this project, the City has established partnerships with two prominent Midwestern energy providers to support the assessment of alternative electric supply options as a means of stimulating the development of two industrial parks located in the City. Because of the type of technology that would provide power to the two sites, the Gas Research Institute has joined the partnership. Other electric powers have made various commitments to the City for various activities.

Project Director: $\quad$ Dwight Bailey, Director of Energy Management

Project Manager: Robert Romo

Department of Environment

30 North LaSalle Street, Suite 2500

Chicago, IL 60602

312/744-8901 Fax: 312/744-6451

\section{Emerging Competition for Electricity: A Municipal Economic Development Opportunity Columbus, $\mathrm{OH}$}

\begin{abstract}
Columbus is interested in offering retail electricity wheeling on its municipal grid, and will conduct a case study for developing local distribution rates. Although rates for interstate transmission have already been established, rates for the local transmission of electricity on the municipal grids do not presently exist. The city will serve as a case study for developing local electricity transportation rates. In addition, attracting new businesses with the incentive of lower cost electricity through retail wheeling will be marketed as an economic development incentive.

This project will determine the electricity transportation rates for retail wheeling/customer choice, the cost analysis of the City's municipal power electricity, and the cost of transporting electricity on the local transmission grid. The project will also propose a fair and equitable rate schedule that will determine the local transportation rates based on factors such as volume used and time of day.

\section{Participants and Partners}

Partners and Participants include the Division on Electricity, American Municipal Power of Ohio, Columbus Division of Economic Development of the Department of Trade and Development, the American Public Power Association/Demonstration of Energy Efficient
\end{abstract}


Development, Electric Power Research Institute (EPRI), the Public Utilities of Ohio, Office of Energy Efficiency (State of Ohio), and the Enron Corporation.

Project Director: James Joyce, Director

Project Manager: Henry Bell

Department of Public Utilities

910 Dublin Road

Columbus, OH 43215-9060

614/645-6141 Fax: 614/645-8019 
Portland's GreenPower Partnership
Portland, OR

\begin{abstract}
Recognizing the trend toward increased customer choice that will accompany electricity restructuring, the City of Portland will develop a "GreenPower Partnership" to offer Portland businesses the opportunity to buy electricity generated by non-hydro renewable resources such as wind, geothermal or solar. Aspects of the project will include renegotiation of the City of Portland's existing purchase contract, and development of a mechanism to allow industrial, government and commercial users, and potentially residential customers, to purchase non-hydro renewable power. This partnership will support the advancement of renewable resource projects planned, but not yet constructed by creating market demand and commitments to purchase the output when production begins.

\section{Participants and Partners}

Partners include Portland General Electric (PGE), Northwest Environmental Advocates, Pacific Northwest Laboratory.

\author{
Project Director: Susan Anderson, Director \\ Project Manager: Curt Nichols \\ Portland's Energy Office \\ 1211 SW Fifth Avenue, Suite 1170 \\ Portland, OR 97204 \\ 503/823-7222 Fax: 503/823-5370
}

\title{
Competitive Franchise Conference and Workshop \\ Barnstable County, MA
}

\begin{abstract}
A leader in addressing the issue of how competitive franchises may be used in a deregulated electricity industry, Barnstable County will conduct a national conference and workshops on competitive franchising to disseminate information, experience and resources regarding the powers available to local governments through the franchise power. Franchise contracts are seen as a way to preserve and continue important utility programs -- such as demand-side management, integrated resource planning, low income assistance -- that are threatened in the transition to a more competitive industry.

This 1997 project is the second phase of a multi-year funding on the use of competitive franchising for electric utility service. The objective of the first year was to commence a research on the concept of competitive franchises for electric services. Barnstable County undertook a study for local governments interested in competitive franchise. The report will include sections on the background of local utility franchise contracts, the mechanisms for competitive franchises, a full discussion of contract issues and a sample RFP and Contract, discussion of stranded investment issues and a discussion on compatibility of the competitive franchise with other proposed restructuring.
\end{abstract}


The purposes of the conference and workshops are to utilize information from the previous year's study, develop and expand expertise within local government, and help build regional networks to share information, experience and resources. Additionally, the conference and workshops are expected to increase industry, media, and public awareness of the powers and options available to local government within the electric utility restructuring. Hopefully, this will help provide local government with a place at the table in utility restructuring discussions.

\section{Participants and Partners}

Participants and partners include Cape \& Islands Self-Reliance, Cities of Portland and Phoenix, and the National Consumer Law Center

Project Director: $\quad$ Margaret Downey, Resource Development Manager

Project Manager: Scott Ridley

Superior Court House

P. O. Box 427

Barnstable, MA 02630

508/362-2511 Fax: 408/362-3608 


\section{ENERGY USAGE AND SUPPLY}

Local governments face continuing requirements to cut energy usage and costs. Application of new technologies expressly suited to local climatic and other conditions is a high priority. In addition, local governments are interested in exploiting local energy resources, particularly non-fossil resources. Many opportunities in this area arise from local governments' responsibilities in waste and wastewater management. In addition, in different regions of the nation, additional supply options, such as fuel from biomass, may make economic and technical sense.

The UCETF 1997 program includes five projects examining various aspects of the energy supply usage. These are:

Phoenix, AZ

Yolo County, CA

Mayaguez, PR

Chittenden County, VT
Toward Sustainability: Waste Minimization and Digester Gas Utilization at a Large Wastewater Treatment Plant

Methane Enhancement for Energy Generation by Accelerated Landfill Decomposition

Solar-Assisted Air-Conditioning and Dehumidification System for Applications in Puerto Rico:

Demonstration Phase

Expanding the Biomass District Energy Opportunity 
Toward Sustainability: Waste Minimization and Digester Gas Utilization at a Large Wastewater Treatment Plant

Phoenix, AZ

\begin{abstract}
This project will investigate waste minimization and digester gas utilization at a large wastewater treatment plant. The project will produce a feasibility study identifying alternative methods for handling sludge and digester gas, and research and develop options for process changes to help increase efficiency of wastewater treatment. The objective of the research is to identify the most practical and economic solution for converting waste into a valuable asset, potentially by kiln drying sewage sludge and producing marketable grade fertilizer using digester methane. Systems to be researched include existing 'cement' style kilns, combustion turbine fired kilns, burner fired kilns and various sludge handling equipment.
\end{abstract}

\title{
Participants and partners
}

This includes the State of Arizona, Department of Commerce, the city of Phoenix Water Services and Public Departments.

Project Director: William Murphy, Energy Management Administrator Project Manager: Dimitrios Laloudakis, Energy Management Superintendent Public Works Department 2631 South 22nd Avenue

Phoenix, AZ 85009 602/262-7897 Fax:602/534-1519

Methane Enhancement for Energy Generation by Accelerated Landfill Decomposition Yolo County, CA

\begin{abstract}
Yolo County has worked in partnership with other local governments in California to accelerate the rate of generation of methane in landfills and maximizing the capture of the resulting gas. Other objectives of this project are to monitor the biological conditions within the landfill cell, demonstrate that the re-circulation of leachate is an effective leachate treatment strategy, and to estimate the landfill life extension that can be realized through the rapid conversion of land-filled solids to gas and liquid. This project will also provide regulatory agencies with information that can be used to develop guidelines for the application of this technology, to better understand the movement of moisture through landfills, and, to assess the performance characteristics of shredded tires as a medium for the transfer of landfill gas to collection point.
\end{abstract}

\section{Participants and Partners}

The participants include the California Energy Commission, Yolo County, Sacramento County and the California Integrated Waste Management Board. 
Project Director: Ramin Yazdani

Project Manager: Rick Moore

Public Works Department

600 A Street, Room 158

Davis, CA 95616

916/757-5567 Fax: 916/757-5570

Solar-Assisted Air-Conditioning and Dehumidification System for Applications in Puerto Rico: Demonstration Phase

Mayaguez, PR

\begin{abstract}
Puerto Rico currently depends on about $98 \%$ conventional imported oil, gas and diesel based systems to generate electricity. This dependence on conventional fuels combined with the aging existing power plants and the steady economic growth have resulted in a limited generation capacity at extremely high costs -- significantly higher than in the mainland US.
\end{abstract}

Solar energy technologies present an environmentally sustainable alternative to supplement electrical energy production in the Caribbean due to the high and uniform insulation available in tropical climates. Due to the year round hot and humid climate in the Caribbean, the industrial and commercial sectors in Puerto Rico use more than $25 \%$ of their energy for room comfort and dehumidification purposes and this amount is even higher when the government sector is included.

Solar-assisted air conditioning and dehumidification systems are the logic choice to offset electricity consumption in a sustainable manner. They have been proven to be economically feasible elsewhere for dry climates. This project will feature design of a pilot system for an existing facility, determination of the economic and technical feasibility of the technology, and outline of a technology transfer plan. This project will also deal with the installation of a demonstration solar-assisted air conditioning system to determine the actual feasibility and characterize the operation of a solar-assisted cooling and dehumidification system.

\title{
Participants and Partners:
}

The participants and partners include A/C \& Mechanical Services Corp., National Renewable Energy Laboratory, Puerto Rico Energy Affairs Administration, Sandia National Laboratories, The Caribbean Island National Wildlife Refuge, the University of Puerto Rico-Mayaguez Campus.

Project Director: Nohemi Zerbi

Project Manager: Prof. Jorge E. Gonzalez

Energy Affairs Administration

P. O. Box 5887

Puerta de Tierra, PR 00906

787/721-4370 Fax: 787/721-3089. 
Expanding the Biomass District Energy Opportunity

Chittenden County, VT

\begin{abstract}
This project is aimed at expanding the opportunity for biomass district energy systems. Aspects of the project will address institutional capacity and the support needed for implementation of a biomass district energy system; assess the economic impact of biomass DHC in job creation, retaining energy dollars in local economy, increasing local economic vitality and competitiveness, and creating environmentally benign sustainable resource based infrastructure; consider environmental impacts, including a review of forest management practices; and identify the benefits of using biomass district energy to address landfill capacity and methane emissions issues. The study will also research the barriers keeping this technology from the broader market, to collect and summarize information on the technology and the market, and to disseminate it to local officials. This will hopefully raise the consciousness about the benefits to the environment and the potential boost to local economies which biomass district heating promises.
\end{abstract}

\title{
Participants and Partners
}

They include: Association of Planning and Development Agencies, Central Regional Planning Commission, Rutland Regional Commission, Department of Public Service, City of Montpelier, Rutland Housing Authority, University of Vermont, Fletcher Allen Health Care, U.S. Forest Service, Northeast Regional Biomass Program, Oakridge National Laboratory.

Project Director: Debra L. Sachs, Planning Specialist

Project Manager: Timothy M. Maker, Technology Director

Chittenden County Regional Planning Commission

66 Pearl Street

Essex Junction, VT 05453

802/658-3004 Fax: 802/879-3610 


\section{ENERGY EFFICIENCY FOR LOCAL NEEDS/ECONOMIC DEVELOPMENT}

Energy efficiency activities can contribute to creation of a sustainable urban environment. Energy efficiency efforts have the potential to affect many of the most fundamental responsibilities of local governments, from service delivery to assisting residents to encouraging economic growth. Urban governments also have important roles to play in bringing energy efficiency technologies and techniques into the marketplace. Urban areas are well positioned to serve as test-beds for such technologies, as part of an overall effort to increase energy efficiency. Enhanced cooperation in identifying promising technologies and refining and applying those technologies to meet specific urban needs continues to be a principle mission of the UCETF.

The link between energy costs and economic development has been well documented. There are a variety of local opportunities in a sustainable community approach to reduce energy consumption having a direct relationship with commerce and industry, social equity, efficient transportation, and environmental quality. In the area of technology applications, a number of emphases can be defined: retrofit applications; end-use metering; new design/renovations; thermal energy storage and cogeneration; energy efficiency in manufactured housing; appliance use and efficiency; model programs and technology demonstrations/proof of concepts; elimination of institutional barriers through cooperative ventures; use of appropriate technologies in renovations, model housing, model public facilities; community energy systems. Each of these can contribute to a sustainable urban energy system.

The UCETF continues to focus on projects that make the linkage between energy, environmental and economic imperatives in local communities. The range of projects selected for the FY 1996 program demonstrates the breadth of issues of concern to urban governments. Through these projects, the UCETF intends to provide concrete examples -pathways if possible -- to be followed by other local governments on how to integrate energy considerations into other policy disciplines in a way that supports local needs.

San Francisco, CA

Albuquerque, NM

Hennepin County, MN

Honolulu, HI

Memphis, TN
Power in Numbers -- Aggregating Small Businesses

Conservation Guidelines for Public Parks in Arid Regions

Urban Telework Retraining Center

Life Cycle Cost, Operation Cost, Operator Acceptance, and Emission Reduction Analysis of Light Duty Advanced Battery Electric Vehicles in Municipal Duty

Networking \$mart Buildings 
Power in Numbers -- Aggregating Small Businesses

San Francisco, CA

\title{
Abstract
}

This project will provide a comprehensive package of services that respond to the market barriers faced by both small businesses and energy service providers. It will aggregate the small business marketplace for energy efficiency improvements in order to provide a mechanism for energy service providers to penetrate this market. The benefit would be that the Agency will handle everything, and would look out for their interests -- thereby minimizing problems of uncertainty, risk, financing, etc. It will produce a program design and business plan for a full service, "onestop shop" small business energy assistance program, including auditing, design, installation, project management, etc. By bringing smaller businesses together, the City will provide for a cost-effective efficiency improvements in the small business sector, freeifrg resources to be used by businesses for jobs creation and retention and economic growth.

\section{Participants and Partners}

Partners and participants include The Small Business Development Center, The Council of District Merchants, The Mayor's Office of Business and Community Services, The Green Ribbon Panel, the Regional Environmental Business Resource and Assistance Center, 3D/International, Landis \& Gyr Powers, Inc., Lawrence Berkeley Laboratory.

Project Director: John F. Deakin, Director

Project Manager: Cal Broomhead

Bureau of Energy Conservation

1155 Market Street, 4th Floor

San Francisco, CA 94103

415/554-3180 Fax: 415/554-3181

Conservation Guidelines for Public Parks in Arid Regions Albuquerque, NM

\begin{abstract}
The main objective of this project is to develop guidelines that provide for a $30 \%$ reduction in water use and a corresponding reduction in energy use, integrating new technologies into computer controls for water distribution in parks. Effective water conservation measures will save both water and energy. The City will consider the use of both stand-alone PV and centralized computer controlled systems for sprinklers and controllers.
\end{abstract}

\section{Participants and Partners:}

Partners include the Irrigation Association, the Scotts Company 
Project Director: Mike Minturn

Project Manager:

Parks and General Services Department

1801 Fourth Street, NW

Albuquerque, NM 87102

505/768-5300 Fax: 505/768-5305

\title{
Urban Telework Retraining Center \\ Hennepin County, MN
}

\begin{abstract}
This project will undertake an innovative effort to combine the telework centers with job training. It will bring suburban jobs to urban neighborhoods through development of telework and retraining centers. Local employers would use the telework center for their needs, while local government will use the center as retraining facility to train individuals in specific job skills and give them experience in work-like environment. The planning and development process will determine criteria for locating centers, equipment and design requirements, training resource development, and outreach programs.
\end{abstract}

\section{Participants and Partners:}

Partners and participants include Downtown Minneapolis Transportation Management Organization, Hennepin County Training and Employment Assistance, International Council for Local Environmental Initiatives, Metropolitan Council, Minnesota Department of Trade and Economic Development, Minnesota Department of Transportation, Resources, Inc. and Midwest Institute for Telecommuting Education, Humphrey Institute of Public Affairs.

Project Director: John McLaughlin, Planning Manager

Project Manager: Robert Luckow, Planning Analyst

Training and Employment Assistance

300 South Sixth Street

Minneapolis, MN 55487-0012

612/348-8912 Fax: 612/348-3932

Life Cycle Cost, Operation Cost, Operator Acceptance, and Emission Reduction Analysis of Light Duty Advanced Battery Electric Vehicles in Municipal Duty

Honolulu, HI

\begin{abstract}
The City of Honolulu will look at the introduction of electric vehicles into municipal duty cycles -- where it makes sense, what the benefits are -- an important focus for local governments in light of the possible future requirements for use of alternative fueled vehicles. The goal of the project is to allow municipal fleet and purchasing departments to
\end{abstract}


make informed decisions regarding the use of electric light duty pickup trucks. The project will generate data for 12 months of actual vehicle operation in municipal duty cycles.

\section{Participants and Partners}

Partners include the State of Hawaii's High Tech Development Corporation, California Air Resources Board, South Coast Air Quality Management District, University of Hawaii. Other companies are GNB, Optima Battery, Electrosource Battery, Powercell Battery, SAFT Battery, CARB, and GM Delco Propulsion Systems.

Project Director: $\quad$ Ross Sasamura, Assistant Chief

Project Manager: Jack Brown, General Manager

Department of Public Works

160 Ahui Street

Honolulu, HI 96813-5510

808/523-4171 Fax: 808/538-7899

Networking Smart Buildings

Memphis, TN

\section{Abstract}

The City of Memphis is committed to reducing the energy costs associated with operating its facilities. The City will investigate opportunities to centralize monitoring and control of HVAC equipment by electronically linking city buildings through a building automation network. The project will examine available building automation technologies, estimate the DSM potential offered by a citywide network, determine the economic feasibility threshold for adding facilities to the network and include a pilot installation of a network to demonstrate the energy savings potential.

\section{Participants and Partners}

Project partners include almost all divisions within the City. The Department of General. Services will be the primary partner.

Project Director: Dexter Muller, Director

Project Manager: Cliff Norville, Manager

Division of Planning and Development

125 N. Main Street, Room 468

Memphis, TN 38103

901/576-7197 Fax: 901/576-7188 


\section{TECHNOLOGY TRANSFER}

Both the US Department of Energy and the Urban Consortium Energy Task Force (UCETF) continue a strong commitment to enhanced technology transfer. To this end, the UCETF specifically solicited technology transfer projects to be conducted by local jurisdictions. The UCETF will conduct five projects specifically designed to document and transfer lessons learned through local government energy programs. From these projects, the UCETF intends to create a variety of technology transfer tools, including reports identifying key issues for jurisdictions seeking to introduce new technologies, how-tomanuals, software packages, and direct technology transfer through workshops and conferences.

The following are the 1997 Technology Transfer projects:

Chula Vista, CA

San Francisco, CA

Montgomery County, MD

Dade County, FL

Tucson, AZ
City of Chula Vista Telecenter

Boiler Efficiency Improvement Program Guidebook

Multi-media Energy Design Guidelines

South Florida Sustainable Buildings Conference, Exhibition, and Design Competitions

Institutional Barriers to Straw-Bale Construction 
City of Chula Vista Telecenter

Chula Vista, CA

\begin{abstract}
This project will document the results of its telecenter project to provide guidance on how to make telecenters work. The Chula Vista case study will demonstrate energy savings through data collection, and evaluate the overall effectiveness of the telecenter program based on occupancy rates, shared usage and energy savings. A guidebook featuring topics such as development of marketing and business plans, how to operate a center, and how to recruit and educate managers and employees in developing a successful telecommuting program, will be included.
\end{abstract}

\title{
Participants and Partners
}

The participants and partners include various agencies such as the Transportation Management Associations, the County of San Diego Air Pollution Control Department, and Ride Link in the City of San Diego.

Project Director: Barbara Bamberger, Environmental Resource Manager Project Manager: Angie Jarchow Department of Administration and Environmental Services 1550 East H Street, Suite J

Chula Vista, CA 91913

619/691-5296 Fax: 619/656-3087

Boiler Efficiency Improvement Program Guidebook San Francisco, CA

\begin{abstract}
The main objective of this project is to assemble a "Boiler Efficiency Improvement Program Guidebook" for municipal energy managers. The City will translate its successful experience in energy conservation through boiler maintenance into a manual. The City has developed a comprehensive boiler preventative maintenance and retrofit program, and through this project, that expertise will be packaged into a tool including proven strategies in comprehensively maintaining and cost effectively improving the efficiency of existing municipal boilers.
\end{abstract}

\section{Participants and Partners}

The City of Berkeley is a partner and will test all the elements of the Guidebook through direct application in their boiler maintenance program. 
Project Director: John F. Deakin, Director

Project Manager: Bruce Chamberlain

Bureau of Energy Conservation

1155 Market Street, 4th Floor

San Francisco, CA 94103

415/554-3180 Fax: 415/554-3181

Multi-media Energy Design Guidelines

Montgomery County, MD

\begin{abstract}
This project will bring energy efficient design into the age of multi-media communications. The interactive and educational capabilities of multi-media will be harnessed to engage and educate designers to improve energy efficiency practices. Advanced Energy Design Guidelines will be placed on CD-ROM and enhanced with supplemental programs, graphic interfaces, and updated technical information from Internet sources.
\end{abstract}

\title{
Participants and Partners
}

Montgomery County will provide in-kind contributions to the project matching federal dollars one-to-one. Staff architects, engineers and information systems specialists across departments will contribute time and resources. Software contributions are from Hydrotherm (high-efficiency boilers) and Automated Logic (DDC Controls). The Maryland Energy Administration (state energy office) will promote the products through their publications.

Project Director: Paul Tseng, Chief of Engineering Services

Project Manager: $\quad$ Ronald J. Balon, Senior Energy Engineer

Department of Facilities and Services

Capital Projects Management Division

110 North Washington Street, Third Floor

Rockville, MD 20850

301/217-6091 Fax: 301/217-6003

South Florida Sustainable Buildings Conference, Exhibition, and Design Competitions Dade County, FL
Abstract
Dade County will hold a conference to address aspects of sustainability and energy efficiency. The conference will target users, architects, builders, regulators, and researchers. It will feature sessions on sustainability in planning, design, construction, rehabilitation, operation and demolition of commercial and residential buildings. This conference will use elements of two previously held conferences in North Carolina and Washington, DC. 


\section{Participants and Partners}

Partners include the Dade Green Coalition (consisting of County government departments, private companies, not-for-profit organizations, and three universities of Dade County).

Project Director: $\quad$ Douglas Yoder, Assistant Director

Project Manager: Don Youatt, Facilities Engineer

Environmental Resources Management

111 NW First Street, Suite 1310

Miami, FL 33128

305/375-3303 Fax: 
Institutional Barriers to Straw-Bale. Construction

Tucson, AZ

\begin{abstract} institutional concerns comprehensively.

\section{Participants and Partners} the project partners and participants.

Project Director: Joseph Comella, Director

Project Manager: $\quad$ R. Bruce Woodruff

Community Services Department

1501 N. Oracle Road

P. O. Box 27210

Tucson, AZ 85726-2710

520/791-4171 Fax: 520/791-5648
\end{abstract}

The purpose of this project is to document the barriers to straw bale construction for affordable, energy efficient housing. This building technology offers wide array of advantages, using annually renewable readily obtainable agricultural waste product to build an affordable, super-insulated wall system. The project will address institutional resistance to new building techniques in order to make straw bale wall system acceptable to those who control construction. Input will be sought from code officials, bankers, insurers, appraisers, architects, engineers, realtors and builders to product package of material that addresses

Coalition Members, The Metropolitan Energy Commission, and Access Tucson are some of 